\title{
The Role of Organizational Culture in Improving Employee Performance in The Era of Globalization
}

\author{
Ahmad Sahal Gojali*, Anysha Rahmasuri, Eneng Selvi, Rahmi Rahmawati Sayyidah, Riyan Mirdan \\ Faris, Kharisma, Bagja Rahma Putra
}

Nusa Putra University, West Java, Indonesia

*Corresponding author:

E-mail:

ahmad.sahal_mn19@nusaputra.ac.id

\begin{abstract}
The purpose of this study is to determine how the Role of Organizational Culture in Improving Employee Performance in the Age of Globalization. This research is a type of descriptive qualitative research, namely research based on data that is then collected in the form of words and not in the form of numbers. Data collection is carried out in this study using secondary data techniques, which are generally secondary data in the form of documentation data or existing report data. From this study, the authors took from books and journals as secondary data. The research results indicate that it turns out that in improving employee performance one of the influences is the role of organizational culture. Having a culture in an organization will make its employees have the same perspective in carrying out their work activities because the organizational culture that exists in a company is a reflection of its employees. The existence of employees in an organization aims to change and develop the organization into an organization that can compete competitively in the era of globalization and can also make the organization superior. Amid globalization which is rapidly undergoing many unexpected and unpredictable changes, a leader must place himself following the demands of a global organization and have a strong leadership attitude. That way, foreign cultures that enter this era of globalization can be well accepted and instilled. by instilling global organizational values in the existing organizational culture and building good communication with employees to make these values a shared value. When leaders can make cultural values that are included in this era of globalization as shared values, employees will be familiar with cultural changes. So that their performance will not be disturbed, and even tend to increase.
\end{abstract}

Keywords: Organizational culture, Globalization

\section{Introduction}

Increasing employee performance in the current era of globalization is very much needed. When the environmental company is very fast and complex, the organization is a container in a group of people who work together to achieve common goals both formally in an alliance of a group of people called leaders and subordinates (Siagian, 1997)

When establishing a company, of course, there must be considerations such as the organizational structure and organizational culture contained therein. Organizational development in this globalization era has very high competition, while the quality of employee performance in the organization can be seen from its human resources.

Without the role of humans, organizations will not run well even though various factors are needed. Therefore, humans as a means of driving and determining the course of an organization in a company. In fulfilling the goals of a company, employees can directly encourage productivity, if the company has good human resources, the company can compete with other companies as well.

Humans always play an active role in determining the designs, systems, processes, and goals to be achieved by the Hasibuan company (2000). Therefore, human resources are a very important factor for

\section{How to cite:}

Gojali, A. S., Rahmasuri, A., Selvi, E., Sayyidah, R. R., Faris, R. M., Kharisma, \& Putra, B. R. (2021). The role of organizational culture in improving employee performance in the era of globalization $1^{\text {st }}$ ICEMAC 2020: International Conference on Economics, Management, and Accounting. NST Proceedings. pages 176-181. doi: 10.11594/ nstp.2021.1021 
organizational development. The three factors that are very influential in company performance according to Gibson et al. (1987) entitled Organization and Management: Behavior Structure, Process, can be seen that: (1) individual factors; skills, work experience, social level, and education science or demography (2) physiological factors; perception, job satisfaction, motivation, and personality (3) organizational factors; organizational structure, leadership spirit, job design, and acclamation or reward systems.

Organizational culture in an organization will greatly affect the performance that is carried out in a company, besides that organizational culture is also a place where someone can assess and influence the work they do. As the notion of organizational culture itself is a shared meaning system adopted by each of its members that differentiates one organization from another (Robbin, 2003). From the above understanding, it can be seen that what is meant by organizational culture is a system of behavior that an organization has to differentiate from other organizations.

In an organizational culture in a company, it will be considered the same in building commitment to realize a vision that will later win the hearts of customers as well as competitors as a strength in the company (Mangkusono, 2007). The creation of a strong organizational culture, it will make a company increase the effectiveness of its employees because organizational culture is a character that must be owned by a company in distinguishing other companies. A strong organizational culture will make a company able to compete with other companies in the era of globalization. Therefore, to achieve company success, it is necessary to increase employee performance by creating and growing an organizational culture.

\section{Theoretical Review}

Organizational culture has the following meaning, According to Robbins in his book Organizational Behavior (1996) defines that organizational culture is a shared system used by members in an organization that functions to differentiate one organization from another.

Organizational culture is a culture that a company has that makes all work easier to do. With an organizational culture, communication and coordination within a company will run better, because employees will know their respective capacities and functions. because of organizational culture as well, the distance between subordinates and superiors which is often a barrier to employee performance will not be too obvious, but it also does not remove the boundaries that apply like an employee to his superior

According to Mondy and Noe (1996), organizational culture is divided into two types, namely: (1) Closed and Autocratic Culture, which is characterized by the achievement of a company or organization goal with strong and dictatorial leadership; (2) Open and Participative Culture, this type of organizational culture are characterized by the fulfillment of a company's goals with democratic leadership.

Employee performance has the following meaning, According to Dessler (2000) Performance has meaning of a comparison between the work achieved with the work standards that have been implemented by the company.

Performance is the work result of an employee in a company in the form of quality and quantity in doing work following the responsibilities that have been given to him.

In a company or organization, an employee or member will have satisfactory performance if there is a match between the job and the abilities he has. When an employee has been able to find a match between his job and his abilities, a sense of responsibility for his job will emerge and employees will try to improve their performance to help the company achieve its goals.

Globalization is an event or the process of forming a new global order without recognizing any boundaries, both regional boundaries and boundaries in the realm of life.

Globalization is marked by the development of technology, with the existence of technology, there are no more boundaries between regions and countries. Good boundaries in terms of education, politics, business, and other areas of life. Globalization is also initiated or marked by the entry of new cultures which will sooner or later shift existing cultures. For this reason, an organization must be able to accept and cultivate a new culture that has entered so that the organization can keep up with the times without eliminating the existing culture. 


\section{Material and Methods \\ Types of research}

This type of research used in this research is to use the literature review method based on qualitative methods sourced from journals. A literature search from international journals originating from ScienceDirect. The journals we chose were those that had something to do with organizational culture, employee performance, and globalization. Because the purpose of this research is to examine the existence of the subject to be studied. Also, this type of qualitative research has alleged legal rules, research strategies, methods of data collection, analysis to be discussed, and also interpretations of various data. In qualitative procedures prioritizing data in the form of writing and images, this study has a unique step in analyzing data because the data comes from different research strategies. The purpose of descriptive research in this study is to create a systematic, factual, and reliable depiction of the nature of the population in an area. This research, it was conducted in two ways, namely by collecting data and documents.

\section{Data sources}

Sources of data used in this study come from secondary data sources, which are generally secondary data in the form of documentation data or existing report data. Because the type of data comes from secondary data, the authors take from books related to this research and also journals.

\section{Data collection methods}

This research is also included in research with data collection techniques, where the research is carried out by reviewing data that has a relationship with the problem being studied. Therefore, to obtain data in this study, the authors use the method of documentation, documentation, namely the trick of collecting data that is not aimed directly at the subject to be studied. In documents, the researcher examines data sources in the form of written objects such as books, journals, documents, meeting minutes, daily notes, or others.

\section{Results and Discussion}

An organization is formed from a group of people who have the same goals. Because basically, humans are social creatures who cannot live alone and will need other people in their daily lives. Therefore, humans live in groups and form an organization to meet their own needs. From the gathering of these people, it will then create a social environment within an organization which is caused by several factors, which can be seen from the superiority of the leader in the organization, the provisions, norms, and judgments of the organization, the bonds that exist between the leader and its employees, and also between existing work partners. Every organization can develop if each member can maintain a good relationship with the environment.

In an organization or company, there is a habit that applies, where this habit is called an organizational culture which is basically according to Robbins and Judge (2008). In his second book on Organizational Behavior it can be concluded that there are three ways in the process of creating organizational culture, namely: (1) As a company founder, they usually accept and retain employees who have the same goals. This can be seen from the mindset between leaders and employees who are aligned and have the same feelings. (2) Leaders pass on education to their employees and also apply the same way of thinking to suit company goals. (3) Leaders will act as a good example for their employees to follow to motivate their employees to work. Culture in an organization usually comes from the work habits that are built in the organization or company. According to Ancok (2012) explaining the origin of organizational culture, it can be seen that culture in an organization usually comes from work habits that are built in the organization or company. The founders of the company will form and build their own organizational culture which will then be introduced to their employees from time to time. In an organization, of course, there are many problems faced by members of the organization, one way to solve existing problems is by studying and understanding the organizational culture that exists in it. By making culture a reference for solving problems, these problems will be quickly resolved. 
When the company founders have found employees who are in line with the organizational culture, it will make it easier for employees to carry out their respective duties. Because organizational culture in a company is a reflection of its employees. The existence of employees in an organization aims to change and develop the organization into an organization that can compete competitively in the era of globalization and can also make the organization superior to other organizations.

Organizational culture can change over time according to the demands of organizational development, therefore organizational culture is called dynamic. Like in the current era of globalization where a lot of cultures have entered and will certainly affect the existing organizational culture. Therefore, the culture contained in the organization must be able to change according to developments that occur.

With the development of times and technology, organizational culture can be updated in various aspects depending on the company itself. Culture produces a structure that can be accepted by all parties, meanwhile, a standardized organizational structure will produce work values and work patterns which in turn will produce a new culture. In an argument which is illustrated in picture form, describe the relationship between culture and structure: (1) structure based on function; (2) Structure-based on division; (3) matrix-based structure; (4) Structure-based on culture and organization.

In the current era of globalization, the competitive situation in the business world is getting stronger. For this reason, many companies compete with each other to advance the company to improve performance so that the company's condition is superior and competitive to balance the competition in the era of globalization. In advancing the company, technological advances play a very strong role in a company, especially in increasing the efficiency and effectiveness of employees in completing their duties, for that the company makes human resources a benchmark for the success of companies in the era of globalization.

One of the extensive studies conducted by Kotter and Heskett (1992) on 207 organizations in America. His research supports previous studies which concluded that organizational culture has a significant impact on the company's long-term economic performance. Their research also concluded that in the coming decade's organizational culture will even more determine organizational success or failure because, in an era of rapid change, non-adaptive organizational culture will hinder a company's ability to change its strategy or tactics to face competition.

The era of globalization is very influential on employee performance because, in the current era of globalization, a company is required to always improve employee performance. Every company certainly has a target or goals to be achieved in a certain period, these targets are unlikely to be realized without adequate resources. Therefore, in this era of globalization, the company will continue to improve the performance of its employees to achieve the company's targets or goals. Likewise with organizational culture, in line with the idea that organizational culture is dynamic, which means it can change according to the demands of organizational change. So in this era of globalization, organizational culture in a company will change according to the times.

The influence of globalization on an organization will cause various kinds of impacts, both positive and negative impacts. The positive impact of the influence of globalization on an organization is that it can bring about diversity that comes from gender, race, ethnicity, culture, customs, habits, and also the abilities they have. In addition to its positive impacts, there are also negative impacts, namely globalization makes us not independent, which means having an interdependent attitude between organizations. Then from a lifestyle that tends to follow western culture which is considered to have many advantages. A company may be looking for sources of input in the international market, because all its needs have not been met, such as looking for raw materials, funds, as well as scientific knowledge, which can be sought in the very broad international market. According to Robbins and Judge (2008), in their second book on Organizational Behavior, it can be concluded that there are many challenges faced by organizations in this era of globalization, one of the biggest, most fundamental, and most extensive challenges, which is personal. everyone in the organization, because each individual has differences. A sense of individualism can arise because they consider themselves deserving of a higher position in the company, such as employees who come from developed countries and also employees who feel that they come from a high ethnicity, they will think of themselves as superior to others and feel they deserve to get a 
high job too. If a sense of individualism arises, it will create a sense of indifference between fellow organizational behavior. That is the biggest challenge for a leader in facing the organizational culture that is entering the era of globalization. Where the leader must be able to manage all the differences so that they become the same thought to easily achieve organizational goals.

Through culture in the organization, which has a very big role in improving the performance of its employees is held by a leader. The leader's role in developing organizational culture lies in the communication system, a leader must be able to build good communication with his employees. By establishing good communication between leaders and employees, or between colleagues, it will make the running of organizational culture easier. Organizational culture has a very important role, namely organizational culture as a tool that can determine where the organization is going and also to know and direct what things can and cannot be done in the organization. In the era of globalization that is rapidly changing, a leader must place himself following the demands of a global organization and have a strong leadership attitude. That way, foreign cultures that enter this era of globalization can be well accepted and instilled. by instilling global organizational values in the existing organizational culture and building good communication with employees to make these values a shared value. When leaders can make cultural values that are included in this era of globalization as shared values, employees will be familiar with cultural changes. So that their performance will not be disturbed, and even tend to increase. by instilling global organizational values in the existing organizational culture, and building good communication with employees to make these values a shared value. When leaders can make cultural values that are included in this era of globalization as shared values, employees will be familiar with cultural changes. So that their performance will not be disturbed, and even tend to increase. by instilling global organizational values in the existing organizational culture, and building good communication with employees to make these values a shared value. When leaders can make cultural values that are included in this era of globalization as shared values, employees will be familiar with cultural changes. So that their performance will not be disturbed, and even tend to increase.

\section{Conclusion}

Along with the development of times and technology, organizational culture can be updated in various aspects depending on the company itself. In the era of globalization that is rapidly changing, a leader must position himself following the demands of a global organization and have a strong leadership attitude. That way, foreign cultures that enter this era of globalization can be well accepted and instilled. by instilling global organizational values in the existing organizational culture and building good communication with employees to make these values a shared value. When leaders can make cultural values that are included in this era of globalization as shared values, employees will be familiar with cultural changes. So that their performance will not be disturbed,

For this reason, top leaders have a very decisive role in instilling global organizational values and motivating employees to make these values a shared value. Culture in an organization at least plays a very important role. namely giving identity to its members, increasing commitment to the vision and mission of the organization. When the organizational culture is strong, each member will feel that they are part of the organization. The feeling of being part of the organization will strengthen its commitment to the vision and mission of the organization. Culture will also direct the behavior of organizational members.

One factor that determines the success of planting and changing organizational culture supported by national culture is the role of top leaders as role models in cultural change. In organizations whose top leaders have values that are following the demands of global organizations such as efficiency (because they are free from corruption and collusion) and have strong leadership, global culture can be instilled and adopted even though it requires hard effort and high commitment. Global organizational culture demands flexibility, speed, efficiency, and customer service. 


\section{Suggestion}

Based on the conclusions about this review literature journal research, the authors suggest that company founders who have a big influence in improving employee performance in this era of globalization should be able to get employees who are in line with the organizational culture, such as recruiting new qualified employees and retain old employees who affect company performance. That way, employees will find it easier to carry out their duties following company goals. In the era of globalization, the number of foreigners who enter the organization will directly impact the existing organizational culture. Therefore, leaders must be able to develop and build good communication with their employees. Then suggestions for researchers,

\section{References}

Ancok, D. (2012). Psychology of leadership and innovation. Jakarta: Erlangga.

Dessler, G. (2000). Human resource management. 8th edition. New Jersey: Prentice-Hall, Inc. Free Press.

Gibson, J. L., et al. (1987). Organization and management: Behavior, structure, process. Jakarta: Binarupa Aksara.

Hasibuan, M. (2000). Human resource management. Revised Edition, PT. Earth Literacy Jakarta.

Kotter \& Heskett (1992). Corporate culture and performance. New York: The

Kotter, J. P. \& Heskett, James L. (1997). Corporate culture \& performance (Benyamin Molan, Penerjemah). Jakarta: Prenhallindo Mangkusasono, H. (2007). Corporate Culture, Challenge to Excellence, editor: Moeljono, D., Jakarta: PT Elex Media Komputindo. Mondy, W., \& Noe, R, M. (1996). Human resource management. Texas: Prentice Hall, Inc.

Robbins P. S., \& Judge. (2008). Organizational behavior book 2. Jakarta: Salemba Empat page 256.

Robbins, P. S. (2003). Organizational behavior. Edition Nine, Volume 2. Indonesian Edition. Jakarta: PT Gramedia Group Index, Robbins, P. S. 1996. Organizational behavior, 7th Edition (Volume II). Jakarta: Prehaliindo

Siagian, S. P. (1997). Human resource management. Jakarta: PT. Mount Agung shop. 